\title{
Reputation and ethical behaviour in a crisis: predicting survival
}

\author{
Tom Watson \\ The Media School, Bournemouth University, Poole, UK
}

\begin{abstract}
Purpose - The purpose of this paper is to explore the interrelation of reputation with corporate performance in a crisis and consider the factors that make up the balance between strong recovery, bare survival and failure. The emphasis is on corporate communication and corporate governance.

Design/methodology/approach - The current debate on reputation and the validity of the term reputation management is reviewed and cases studies from Australia and the UK are examined.

Findings - The paper finds that, in the case studies, poor management, unethical practices, a lack of engagement with customers and other stakeholders, indifferent or aggressive performances by CEOs and lack of preparedness for crisis communication severely or terminally affected the organisations. It identifies a new reputational factor of predictability and considers why some organisations survive a crisis that has strong negative ethical dimensions while others fail.

Originality/value - This paper scrutinises existing concepts of reputation and reputation management and finds that they are not able to predict recovery, survival or failure of organisations. A new definition of reputation is put forward and the factor of predictability is emphasised in proposals for new applied theory.
\end{abstract}

Keywords Ethics, Behaviour, Business performance, Australia, United Kingdom

Paper type Research paper

\section{Introduction}

Reputation is of immense importance to all organisations, whether they are commercial, governmental, or not-for-profit. To achieve goals, remain competitive, and prosper, the received wisdom is that good reputation paves the organisational path to acceptance and approval by stakeholders. It also underpins competitive advantage by demonstrating distinctive differences from other similar organisations. The benefits of a positive corporate reputation are an intangible asset contributing most to overall corporate success (Hall, 1992), that supports premium pricing and product quality (Klein and Leffler, 1981), aids staff recruitment (Stigler, 1962), improves access to financial resources (Beatty and Ritter, 1986) and attracts investors (Milgrom and Roberts, 1986) and inhibits the mobility of rivals (Caves and Porter, 1977; Dowling, 1994).

Argenti and Druckenmiller argue that, "organisations increasingly recognize the importance of corporate reputation to achieve business goals and stay competitive" (Argenti and Druckenmiller, 2004, p. 368). While there are many recent examples of organisations where poor leadership and unethical business practice behaviour have destroyed their reputation, such as Enron, Arthur Andersen and WorldCom, the positive case for reputation is that it fosters the continued expansion of excellent companies such as Johnson \& Johnson and Philips and innovators such as Cisco Systems, which appear regularly in the top percentile of rankings of the most respected organisations in the USA and Europe (Gardberg and Fombrun, 2002).

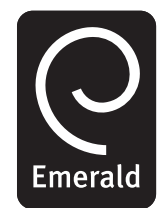

Journal of Communication Management

Vol. 11 No. 4, 2007 pp. $371-384$

(C) Emerald Group Publishing Limited DOI $10.1108 / 13632540710843959$ 
JCOM

11,4

372
In an eight-country study, Kitchen and Laurence (2003) explored corporate reputation management practice. Reputation was found to be of the greatest importance in achieving corporate objectives, with the highest ranking in the anglophone world. A theme of this study was the weight given to the CEO's reputation in determining corporate reputation. Amongst their conclusions were that corporate reputation is increasing in importance; key influencers on reputation are customers, employees and the CEO; corporate reputation and $\mathrm{CEO}$ reputation are increasingly intertwined; and the $\mathrm{CEO}$ is inevitably cast in the role of chief communicator.

What is evident is that reputation does not occur by chance. It relates to leadership, management, and organisational operations, the quality of products and services, and crucially - relationships with stakeholders. It is also connected to communication activities and feedback mechanisms.

This paper explores reputation and reputation management. A new definition of organisational reputation is proposed which is tested in case studies of reputation using recent examples from Australia and the UK.

\section{Notions of reputation}

In the corporate world, reputation is seen as a major element of an organisation's provenance alongside and included in financial performance and innovation. It is socially complex and intangible, highly specific to each organisation and part of a process of "social legitimization" of the organisation (Martin de Castro et al., 2006). There is also an historical aspect (Hall, 1992; Yoon et al., 1993). It is perceptual (Fombrun, 1996; Wartick, 2002), emotive (Groenland, 2002) and comprises affective and cognitive dimensions (Llewellyn, 2002; Schwaiger, 2004). Dowling (1994, p. 8) defines corporate reputation as "...the evaluation (respect, esteem, estimation) in which an organisation's image is held by people". Argenti and Druckenmiller (2004, p. 369) refer to it as "The collective representation of multiple constituencies' images of a company built up over time and based on a company's identity programs, its performance and how constituencies have perceived its behaviour". Fombrun and Rindova (2005) say that it is a collective representation of an organisation's past behaviour and outcomes that depict its ability to render results to stakeholders in the future. This is also reflected in Coombs' scholarship on crisis communication (Situational Crisis Communication Theory) which argues that past crises form a reputational threat to organisation in varying levels of intensity (Coombs, 2004). Llewellyn (2002, p. 447) expands definitions to include affective and cognitive elements: "Reputation occurs as stakeholders evaluate their knowledge of or encounters with an organisation [cognitive] vis-à-vis their expectations, which are couched within their individual values (personal identities) or collective norms [affective]".

The definitions of Dowling, Argenti and Druckenmiller and of Fombrun and Rindova are that reputation is a "collective representation" of images and perceptions, not merely a self-promotional message. It involves relationships with all stakeholders ("constituencies") and is gained, maintained, and enhanced or detracted from over time. For greater understanding of reputation, these primarily organisational management approaches can be improved with the inclusion of emotional (affective/cognitive) elements, as proposed by Llewellyn (2002) and Schwaiger (2004), which separate the perception of the stakeholder from their behaviour. Two case studies - Ansett Airlines 
and Rover - discussed later demonstrate the separation of these factors and the outcomes when they occlude negatively.

A factor that has not appeared prominently in public relations and communications literature is "predictability". In political science and political economy, it is the key factor. "The fundamental appeal and importance of this concept [reputation] for economists, and political scientists influenced by their writing, is that reputation lets actors predict others' moves during strategic interaction, according to the 'extrapolation principle" (Sharman, 2007, p. 20). This principle is "the phenomenon that people extrapolate the behaviour of others from past observations and this extrapolation is self-stabilising because it provides an incentive to live up to these expectations. . By observing others' behaviour in the past, one can fairly confidently predict their behaviour in the future without incurring further costs" (Von Weizsacker, 1980, p. 72).

Fombrun and Van Riel (2004) touch on predictability with a reference that reputation involves stakeholder judgements "about a company's ability to fulfil their expectations" but most definitions and descriptions consider that reputation is a collection of images and behaviours (see Argenti and Druckenmiller, 2004, Dowling, 1994). In public relations, the extrapolation principle has not been explored widely and the case studies that follow will consider its impact in the form of "predictability". While the historical aspect of reputation and the ability to deliver future results is noted (Fombrun and Rindova, 2005), it is not explicated as 'predictability'. Coombs (2004, p. 287) refers to crisis history and crisis type as the basis for planning the communication response, "by accounting for the effects of crisis history, crisis managers can craft messages that more effectively protect the organization's reputational assets" but this relevant advice is aimed at communicators and not the responses of stakeholders and so also falls short of "predictability".

Bringing this discussion together, a new definition of organisational (or corporate) reputation is proposed as: "The sum of predictable behaviours, relationships and two-way communication undertaken by an organisation as judged affectively and cognitively by its stakeholders over a period of time." It will be explored in the case studies and subsequent discussion leading to proposals for new applied theory.

\section{Reputation's value in a crisis}

Fombrun and Van Riel (2004) posit that the value of a corporate reputation is magnified in a crisis because of the loss of physical assets and business momentum, the impact on people assets and the expected clear-up and associated legal costs associated. "Over time, some companies recover dissipated value quickly and the crisis fizzles. Others experience more extended damage. Research suggests that the enduring difference may well lie in how the crisis is handled and what the reputation of the company was beforehand." (Fombrun and Van Riel, 2004, pp. 34-5).

Knights and Pretty (1999, pp. 368-9), studied the impact of major manmade crises on fifteen large companies, ranging from Johnson \& Johnson's response to Tylenol tampering to Heineken's recall of bottled beer because of rumours of glass shards in its bottles. On average, the stocks took an eight per cent loss in value. However, the preparedness and speed of response categorised the companies into "recoverers" and "non-recoverers". The recoverers' stock sagged only five per cent in the first few weeks, while non-recoverers dropped an average eleven per cent. After ten weeks, the recoverers rose an average of five per cent and stayed in "positive territory" for the 
$\mathrm{JCOM}$

11,4

\section{4}

\section{Research questions and testing}

From the literature review and discussion, three questions are explored. These are:

$R Q 1$. What is the influence of reputational asset in adverse commercial conditions, especially where ethical behaviour may be weak?

$R Q 2$. What is the importance of factors such as predictability and of the balance between affective and cognitive attitudes in determining an organisation's progress after a crisis or other adverse conditions?

RQ3. Why do some companies fail to overcome crises and others survive? This also tests the Knights and Pretty (1999) taxonomy of "recoverers" and "non-recoverers".

Three case studies have been chosen from Australia and one from the United Kingdom. As they come from similar business/regulatory environments, there is commonality in the cultural, legislative and media scrutiny environment which reduces these factors as variables. All occurred in the past six years and so offer contemporary comparisons. The four case studies include a national airline (failure), a building materials manufacturer (survivor), a grain exporter (survivor) and a mass market vehicle manufacturer (failure). They have been chosen for the national impact of their behaviours and subsequent plight, and their prominence in media coverage and the similar outcomes of unethical behaviour.

\section{Case studies}

These case studies show reputation and corporate communication under the closest examination of continuing stress and crisis situations. They appear alphabetically and are categorised as Failure or Survival.

Ansett Airlines: reputation loss leads to collapse - failure

After operating since 1937, the long-established Australian airline Ansett collapsed in 2001 after a series of aircraft maintenance crises eroded public confidence. It was the

Recoverers

Initial loss of stock value of five per cent

By 50th day after incident, stock has risen by five per cent over pre-incident stock value

Table I.

Taxonomy - recoverers and non-recoverers
Non-recoverers

Initial loss of stock value of 11 per cent

Unchanged stock value for fifth to 50th day; Cumulative negative stock value of almost 15 per cent, up to a year after incident

Source: Knights and Pretty (1999, pp. 368-9) 
long-term beneficiary of its government's "two airlines" policy which sought to ensure competition. The first crisis came at Christmas 2000 when six of its largest Boeing 767 aircraft were grounded for urgent safety inspections and missed maintenance leaving more than 20,000 people stranded. This was followed at Easter 2001 by a further grounding of the same aircraft to inspect engine mounts for cracks. Four aircraft were found to have the cracks and were taken out of service. In addition, it was found that Ansett had known of the problem with engine mounts for 12 months and had failed to act (Sydney Morning Herald, 2001). Even worse followed when the national air safety regulator grounded all ten Boeing 767s after finding that "one aircraft had flown for more than a day with none of its emergency slides in the operating position" (Easdown and Wilms, 2002, p. 19).

After the Easter crisis, travellers' intentions to rebook for travel by Ansett had fallen to 25 per cent. In response to this, the airline's communication strategy was to place its chief executive before the media in order to apologise to customers and assure them of improvements in the quality of service. Travellers' "intentions" [affective view] rose to 58 per cent and Ansett followed this with a $\$ A 20$ million advertising campaign, entitled "Absolutely" using the chief executive and high-profile sports and entertainment stars (Easdown and Wilms, 2002, p. 20) but this campaign had a boomerang effect on customers. Facing insolvency, Ansett shut down its operations on 15 September 2001.

McDonald (2006) has applied attribution theory to Ansett's problems and using qualitative research found the dominant customer attitude to the airline had been anger directed at it and distrust in the senior executive staff to manage effectively and tell the truth. Because of the maintenance problems which had seen the airline grounded by the government air safety watchdog, passengers and potential passengers had largely perceived the airline as responsible for its own fate. In effect, the passengers' views had a negative affective/cognitive alignment. McDonald also found that the "Absolutely" advertising campaign had a negative effect with one interviewee commenting that the $\$ 20$ million would have been better spent on aircraft maintenance.

Additionally, when crisis messages, such as that delivered by the Ansett CEO, were perceived as lies, anger resulted and negative character attributions were made about company management. Such dispositional attributions revealed strong negative attitudes to those companies caught lying and contribute to the public's lack of trust in the integrity of organisations (McDonald, 2006, p. 10).

Ansett ultimately failed because its accumulated debts and decline in passenger numbers left it insolvent, but, as McDonald (2006) has found, there was profound distrust in all aspects of its communications and performance. As a result the government did not intervene to protect the two-airline competition policy because the airline's behaviour was no politically defendable, with a key reason being that the Ansett's behaviour was no longer predictable. Even the CEO's decision to take the lead on communication with customers through media relations and advertising, often seen as best practice in the management of reputation, was a failure because it reinforced the image of an airline that did not care for the safety of its customers and crews but put its effort into image development.

AWB International: reputation damaged by unethical behaviour - survival Australia has been a major export of agricultural produce since the mid-nineteenth century. Wheat has always ranked highly in importance in volume and value 
$\mathrm{JCOM}$

11,4

376 providing incomes to many thousands of farmers across the nation. There has long been a market for the crop in the Middle East, notably in Iraq, and this continued after the first Gulf War when the United Nations introduced the Oil-for-Food program. For Australia's sole licenced wheat exporter AWB International (the privatised Australian Wheat Board), the Iraqi market provided sales of 10 million tonnes of wheat for more than a decade. This was notionally supplied at market price through a United Nations-approved process.

The Volcker report into the Oil-for-Food program, however, found there was "a sink of corruption" (The Australian, 2005) and that AWB was one of traders with Iraq which engaged in practices that inflated the price of imports and provided income to the Sadaam Hussein regime. The revelation by the Volcker report led to the appointment by the Federal Government of a Commission to enquire into the behaviour of AWB. This enquiry was known as the Cole Commission after its commissioner. Although AWB management had publicly denied any wrong-doing, a succession of witnesses from within AWB or close to it reported that the deceit to disguise kickbacks from the UN was well-planned and persistently undertaken. Because of its behaviour, AWB's legislatively enshrined status as the sole licenced seller of Australian wheat on world markets - known as the "single desk" - came under threat.

The Cole Commission report was released on November 27, 2006. It recommended that 11 former AWB executives and an oil businessman face possible criminal charges for allegedly deceiving the United Nations and Australian government over the scandal. Subsequently, the Government has taken the "single desk" away and handed it to a grower group from 2008 onwards, with an important judgement being that AWB's ethical behaviour was no longer defendable or predictable. AWB has also produced poor financial performance (a 71 per cent fall in half year after tax profits to end of March 2007) (ABC Radio National, 2007) and the loss of its business reputation (a continuing decline in share price). Because it has national commercial interests in Australia which are separate from international trading, AWB is likely to survive as a business but it has almost certainly lost its international reputation and its freedom of operation.

James Hardie Industries: deceptive behaviour damages competitive freedom - survival From the early twentieth century onward, asbestos was mined in Australia and processed into building materials, principally for internal and external wallboards. Houses built with the external materials were given the generic nickname of "fibro houses" after the fibrous asbestos source minerals and there are hundreds of thousands of these humble abodes across the country. In the latter part of the 20th century, it became apparent that many thousands of miners and building workers were suffering from the lung diseases mesothelioma and asbestosis caused by exposure to asbestos fibres. One of the major producers of these asbestos products (from 1917 to 1987) is James Hardie Industries which was faced with increasingly large compensation demands.

In a defensive move, the company moved its ownership offshore in 2001 to Holland and at the same time created a body called the Medical Research and Compensation Foundation which took over the rump of its Australian interests and was to handle compensation claims. At the time of the corporate split, the Hardie issued a news 
release which stated that the $\$$ A293 million it had made available to the Foundation "was sufficient to meet all legitimate compensation claims anticipated from people injured by asbestos products manufactured in the past ..." (New South Wales Government, 2004, pp. 354-5). It also indicated that the move to Holland was to facilitate its international expansion. Actuarial assessments, however, estimated the liability over the next 40 years at $\$ A 1.5$ billion (Sydney Morning Herald, 2004a), although this was recently reduced to $\$ A 1.35$ billion for a projected 12,739 claims (SMH.com, 2007).

In 2004, the state government in New South Wales convened a Special Committee of enquiry into the Medical Research and Compensation Foundation whose aim was to investigate the company's conduct. It found the Foundation did not have sufficient funds to meet all anticipated legitimate compensation claims and was massively underfunded; and that Hardie's statement that returns from the Foundation's investments would cover future liabilities was "fanciful" (New South Wales Government, 2004, p. 358). Commissioner Jackson, who led the enquiry, found that senior management were deliberately dishonest and "prepared to be deceitful" about the extent of asbestos claims. He also found that two senior executives were not credible witnesses (Sydney Morning Herald, 2004b). One of his determinations was that the corporate communications activity in 2001 had been deliberately misleading (Howell et al., 2005, p. 5) and had been planned as such. These activities were undertaken to support Hardie's reputation in the international building materials market and Jackson said that "public relations played a larger than healthy part in the activities of the James Hardie Group” (New South Wales Government, 2004, pp. 358-9).

The outcomes of this period of organisational behaviour and its investigations were that a new chairman was appointed and after a considerable delay the main executives criticised by Commissioner Jackson left the company. In the meantime, several states proposed legislation specifically targeted at Hardie including its removal from all tender lists; while the national trade union movement ran an angry campaign against it. Hardie recently agreed to extend its compensation package and to reduce legal restrictions applied to claimants.

James Hardie has not failed, nor has it lost its place in the world-wide market for building products but it has lost the trust of many as an ethical and responsible business. Although the Australia-wide union campaign has ended, contractors are reluctant to order Hardie products, a doubt that will take many years to eradicate. The company's share price has remained solid, although it consistently trails below the benchmark ASX200. In its latest annual report, Hardie reported a rise in profits in 2006, after a massive loss in 2005 when it had made a provision of $\$ 716$ million for asbestos-related claims (SMH.com, 2007). The improved performance, however, has come from the United States which it could be argued is outside the reputational envelope of the disease-related behaviour. But for purposes of this paper, Hardie's attempt to manage reputation in 2001 signally failed because of the deceptive behaviour of senior executives and the failure of the organisation to correct them quickly. Subsequently, its ability to operate freely has been severely limited by vastly increased government oversight, union antipathy and increased costs for compensation and legal services. It can also be argued that the degraded reputational situation had engendered a loss of predictability in relationships with many key stakeholders, including government which has instituted the major enquiry.
Reputation and ethical behaviour in a crisis

377 
JCOM

11,4

378
Rover - vehicle manufacturer (failure)

The case of Rover (and its antecedents) can be accurately described as a saga because of the longevity of its problems. From the early 1970s, large-scale vehicle production in the United Kingdom was in doubt because of competition from non-UK manufacturers and a range of factors that made profitable production problematic (quality, industrial issues, marketing). By the early 1990s, the Rover group (formerly British Leyland and $\mathrm{BL}$ ) was again foundering. Its then owner British Aerospace sold the business to the German BMW car business. By the late 1990s, BMW which had invested heavily in Rover was losing $£ 2,000$ on every car that was made and sold. Within BMW, Rover became known as "the English Patient", an allusion to the film of the same name, because of its continually sickly condition (Brady and Lorenz, 2005, p. 108).

This brief case study will not chronicle the decline and fall of Rover, which is well documented elsewhere, but review the impact of reputation and corporate behaviour at two crucial points. In 2000, when BMW's exasperation with Rover's performance was reaching a terminal stage, as its market share had slumped to 4.6 per cent and well below the 11.3 per cent when the company was acquired, it undertook "what amounted to a disinformation programme throughout the first quarter..." (Brady and Lorenz, 2005, p. 165) and told staff and car dealers that it was proceeding with a reorganisation and had no intentions of selling Rover. It also made assuring comments to the Industry Secretary Stephen Byers and sought his support for an EU aid package worth $£ 152$ million. In the meantime, BMW was actively touting Rover to competitors and in negotiations with the private equity firm Alchemy to break up the business. When the news of the potential sale to Alchemy broke in March 2000, Rover's reputation amongst all stakeholders sank to a new low. One newspaper headline, "It's all over Rover" (Brady and Lorenz, 2005, p. 171), summed up the sentiment. BMW did not complete the deal with Alchemy and sold the business for a notional $£ 10$ to a group of former Rover managers called Phoenix Holdings. In effect, BMW had destroyed what was left of Rover's reputation with British stakeholders by its action in the "disinformation" activity in the first half of 2000.

Phoenix's ownership of Rover was disastrous and the car maker shut down in 2005. The expected benefit of a return to British ownership stimulating national sales did not eventuate. It can be surmised that while British buyers were sympathetic to Rover (the affective element), they had known about the problems of the marque and its products for 30 years (the cognitive element) and because of the long-term decline in both product and corporate reputation chose not to purchase them. In the Phoenix period, the new management was unsuccessful in turning the business around or engaging the support of key stakeholders, especially the Government which had long ceased to be supportive of Rover. Although there was a long history of political and financial support for Rover, one of the factors in its demise was surely that its behaviour was demonstrably no longer predictable or apparently ethical. In 2005, after being misled by BMW and then Phoenix, it decided to not intervene again in the West Midlands motor industry. That was the end of Rover, which had no beneficial reputation left.

\section{Discussion}

In all the case studies, poor management, unethical practices, a lack of engagement with customers and other stakeholders, indifferent or aggressive performances by CEOs and lack of preparedness for crisis communication severely or terminally 
affected these companies. They also failed the test of "predictability". Using Knight and Pretty's "recoverers" or "non-recoverers" taxonomy, two have staged or will stage weak recoveries (James Hardie and AWB) while the other two were terminal "non-recoverers" (Ansett, and Rover), although BMW as owner of Rover for seven years has bounced back as a strong "recoverer".

$R Q 1$. What is the influence of reputational asset in adverse commercial conditions, especially where ethical performance is weak?

The reputation asset of James Hardie and AWB International, according to their share prices and market sentiment, was high before the crises that engulfed them. Once the exterior wrapping was taken off, both were seen to have weak ethical performances in their operations and relationships with key stakeholders, notably governments. In Hardie's case, it was found to have practiced deception in its communication practices and so had little strength with which to defend the company. This is also the condition that Ansett and Rover found themselves in but their position was worse as both had been in the public eye for problematic service performance for some years, although they notionally had governmental sentiment on their side (respectively, two-airline policy and support for the West Midlands motor industry). Both should have been in a position to survive, if well managed and fully engaged with stakeholders. Both, however, had communication and presentational problems and had failed to create "the historical associations in the minds of publics through strategic communications" that lead to "favourable 'top of mind' visibility" (Gardberg and Fombrun, 2002, p. 385). Rover's path to failure, in retrospect, could have been pre-destined because of the long-term problems of the British motor industry, but with better management and communications, it could have survived in a smaller, more efficient form. The behaviour of BMW, with its "disinformation" in 2000 prior to selling the business and the Phoenix management's failure to engage with stakeholders, activated that destiny of failure and cost thousands of jobs. Ansett, too, failed in its communication and behaviour to leverage the brand name and its historical connection with commercial air transport in Australia to such an extent that Government let it fail rather than support the two-airline policy. The reputational asset of both was effectively non-existent when crises struck.

In summary, all four cases demonstrate that without clearly understood and strongly developed reputational assets, organisations will struggle or fail in adverse commercial conditions.

$R Q 2$. What is the importance of factors such as predictability and of the balance between affective and cognitive attitudes in determining an organisation's progress after a crisis or other adverse conditions?

These case studies, especially the two failures and AWB, demonstrate that predictability is an important factor that has been little recognised. Because the organisation's behaviour became unreliable (Ansett), untrusted in communications (Rover) and unethical (AWB), it was one of the main factors that caused major stakeholders such as governments and regulators to withdraw their support as these companies were no longer predictable. For Hardie, other stakeholders such as unions, the media and state governments turned against it and have limited its commercial freedom. The affective/cognitive balance applies to consumers and non-governmental stakeholders more than governments and was evident in Ansett and Rover where the
Reputation and ethical behaviour in a crisis

379 
$\mathrm{JCOM}$

11,4

380 affective sympathy to both for historical reasons was out of alignment with the cognitive experience of the services of the airline and the carmaker's products. These consumer stakeholders wanted both to continue in operation but chose not to purchase their flights or cars.

In summary, predictability is a new and important factor in analysing and explaining the reputation of organisations in relation to government and regulators, while the affective/cognitive balance is more relevant to the consumer/community interface. Both demonstrate that reputation cannot be interpreted as a single entity.

RQ3. Why do some companies fail to overcome crises and others survive? This also tests the Knights and Pretty (1999) taxonomy of "recoverers" and "non-recoverers"

To an extent, $R Q 1$ and $R Q 2$ have answered the question about failure and survival. The factors that aid survival are ethical behaviour and good corporate governance, two-way communication with internal and external stakeholders, and the ability to build and maintain supportive relationships with these stakeholders. As to why AWB and Hardie survive, although with problems, while Ansett and Rover failed, it is primarily that they were financially stronger before the crises and, subsequently, have been able to separate or "ring fence" their problem areas from other areas of the businesses. Hardie, while besieged in Australia, has prospered in the United States. AWB has Australian-based agribusinesses that have been little affected by the Iraq payments scandal. Both, therefore, have cash flow and business identities that continue little affected by the storm and fury over ethical behaviour. Ansett and Rover did not have the opportunity to separate the problem areas from the successful ones because there weren't any.

In considering the Knights and Pretty taxonomy of recoverers and non-recoverers, the case studies have shown that it is too limited in its scope and should have a third category of "failures". It is also suggested that "non-recoverers" be re-titled as "survivors" (see Table II).

\section{Proposals for applied theory}

In conclusion, these proposals for applied theory are based on the preceding discussion and the testing of definition proposed earlier in this paper that "reputation is the sum of
Recoverers

Survivors (re-naming of non-recoverer)

Table II.

Revised taxonomy recoverers, survivors and failures

Failures
As per Knights and Pretty (1999), after initial loss of stock value ( $c$. five per cent) the stock recovers strongly. Continues operating with same freedom as before the incident

As per Knights and Pretty (1999), the company' stock value falls initially by $c$. 11 per cent, and after a year, remains lower (c. 15 per cent) and consistently below market trends. Is vulnerable to take-over and has limited operational scope

Organisation suffers major loss in stock value and market confidence. Is unable to remain as a separate entity and/or collapses
Source: Knights and Pretty (1999, pp. 368-9), with modifications 
predictable behaviours, relationships and two-way communication undertaken by an organisation as judged affectively and cognitively by its stakeholders over a period of time”.

Reputation has affective and cognitive elements in its make-up. Having one element, such as sympathy (affective) does not - in the cases of Ansett and Rover - sustain an organisation's existence if the cognitive (experience of the organisation) is not balanced with it.

The loss of predictability in Ansett and Rover's cases was one of several reasons that led to withdrawal of government and political support because of the erosion or elimination of their reputation. AWB's ethical and operational performance has resulted in the removal of its valued "single desk status" with predictability also one of the factors because government could no longer support its operations on international markets as being ethical and representative of the country's normal business behaviour.

James Hardie is a partial exception to the cognitive/affective and predictability analyses. Its reputation and operations have suffered within Australia, as evidenced by union boycotts and government regulations, but it has returned to profit from operations in other countries where the asbestos disease issue has little impact. So any claim to universality of these factors may be tempered by the physical situation of the crisis/behaviour (despite the reach of the Internet).

Two proposals for new applied theory are made.

\section{Proposition 1}

Reputation is an asset in a crisis when it has these characteristics.

- Affective and cognitive elements are in an organisationally-beneficial alignment.

- The organisation operates in an historically predictable manner with a set of ethical and organisational behaviours that are acceptable to governmental and other key regulatory stakeholders.

- There is ethical leadership by the CEO and management (dominant coalition) that is supported by two-way communication and engagement with stakeholders.

- The ability to manage the immediate crisis is less important if the organisation satisfies the characteristics of affective-cognitive alignment, predictability and ethical leadership. Without these characteristics, crisis management is likely to be unsuccessful in creating strong "recoverer" conditions and lead to a prolonged struggle for survival.

\section{Proposition 2}

- The taxonomy of "recoverers" and "non-recoverers" proposed by Knights and Pretty (1999) should be revised to: "recoverers", "survivors" and "failures".

- Failure is the most likely outcome for organisations with weak cognitive/affective balance and predictability than survival, especially if they are dependent on goodwill from government and regulators.
Reputation and ethical behaviour in a crisis

381 
JCOM

11,4

382

\section{Limitations and implications}

Apart from the Ansett case study, which reviewed McDonald's (2006) study of attribution by stakeholders, the case studies have been based on published sources and financial data. This limits their generalisability (Coombs, 2007) and future research needs to investigate the cognitive and affective responses of actual or potential stakeholders who are associated with crises caused by problematic ethical behaviour. Future research using situational studies (Coombs and Holladay, 2006; Lyon and Cameron, 2004) could test the propositions, notably that of affective-cognitive alignment, for the consistency of their applicability. Coombs (2004) and Coombs and Holladay (2006) have argued for variable impacts on reputation from different types of crises and the prior history of an organisation in handling crises. Their approach has largely been based on a monolithic structure of reputation. It would be relevant and informative to test the propositions of this paper for a two-part (affective/cognitive) reputation against their modeling of crisis communication that has largely been developed to advise communication practitioners.

The implication of the proposals are that the consideration of reputation as a determinant of post-crisis response and an influence on survival or failure of an organisation should include consideration of two aspects of reputation and whether the notion of reputation as a source of defensive "capital" (Alsop, 2004) is a false one. Predictability of organisational behaviour, this paper has posited, offers defensive value that is potentially greater than the immediate crisis response which is so often the focus of public relations and organisational communication research. It is a factor that has not been explored in detail and deserves greater consideration because of its linkage with a wider range of stakeholders than is offered by current crisis communication theory and best practice.

\section{References}

Alsop, R.J. (2004), The 18 Immutable Laws of Corporate Reputation: Creating, Protecting, and Repairing Your Most Valuable Asset, The Free Press, New York, NY.

ABC Radio National (2007), "National AWB records massive profit slump”, The World Today, 23 May.

Argenti, P.A. and Druckenmiller, B. (2004), "Reputation and the corporate brand", Corporate Reputation Review, Vol. 7 No. 4, pp. 368-74.

(The) Australian (2005), "Feeding a dictator", The Australian, 29 October, p. 18.

Beatty, R.P. and Ritter, J.R. (1986), "Investment banking, reputation and underpricing of initial public offerings", Journal of Financial Economics, Vol. 17, pp. 213-32.

Brady, C. and Lorenz, A. (2005), End of the Road: The True Story of the Downfall of Rover, 2nd ed., Pearson Prentice Hall, Harlow.

Caves, R.E. and Porter, M.E. (1977), "From entry barriers to mobility barriers", Quarterly Journal of Economics, Vol. 91, pp. 421-34.

Coombs, T.W. (2007), "Attribution theory as a guide for post-crisis communication research", Public Relations Review, Vol. 33 No. 2, pp. 135-9.

Coombs, T.W. (2004), "Impact of past crises on current crisis communication", Journal of Business Communication, Vol. 41 No. 3, pp. 265-89.

Coombs, T.W. and Holladay, S.J. (2006), "Unpacking the halo effect: reputation and crisis management”, Journal of Communication Management, Vol. 10 No. 2, pp. 123-37. 
Dowling, G. (1994), Corporate Reputations, Longman Professional, Melbourne.

Easdown, G. and Wilms, P. (2002), “Crash landing”, Herald-Sun, 27 July.

Fombrun, C.J. (1996), Reputation: Realising Value From Corporate Image, Harvard Business School Press, Cambridge, MA.

Fombrun, C.J. and Rindova, V. (2005), "Fanning the flame: corporate reputations as a social construction of performance", in Porac, J. and Ventresca, M. (Eds), Constructing Markets and Industries, Oxford University Press, New York, NY.

Fombrun, C.J. and Van Riel, C.B.M. (2004), Fame and Fortune: How Successful Companies Build Winning Reputations, FT/Prentice Hall.

Gardberg, N.A. and Fombrun, C.J. (2002), "For better or worse - the most visible American corporate reputations", Corporate Reputation Review, Vol. 4 No. 4, pp. 385-91.

Groenland, E. (2002), "Qualitative research to validate the RQ dimensions", Corporate Reputation Review, Vol. 4 No. 4, pp. 308-15.

Hall, R. (1992), "The strategic analysis of intangible resources", Strategic Management Journal, Vol. 13, pp. 135-44.

Howell, G., Miller, R. and Bridges, N. (2005), "Cardinal rule of the media release - get your facts right”, Asia Pacific Public Relations Journal, Vol. 6 No. 2, available at: www.deakin.edu.au/ arts/apprj/currenti.php\#7

Kitchen, P.J. and Laurence, A. (2003), "Corporate reputation: an eight-country analysis", Corporate Reputation Review, Vol. 6 No. 2, pp. 103-17.

Klein, B. and Leffler, K. (1981), "The role of market forces in assuring contractual performance", Journal of Political Economy, Vol. 89, pp. 615-41.

Knights, R.F. and Pretty, D.J. (1999), "Corporate catastrophes, stock returns, and trading volume", Corporate Reputation Review, Vol. 2 No. 4, pp. 363-81.

Llewellyn, P.G. (2002), "Corporate reputation: focusing on the zeitgeist", Business and Society, Vol. 41 No. 4, pp. 446-55.

Lyon, L. and Cameron, G.T. (2004), "A relational approach examining the interplay of prior reputation and immediate response to a crisis", Journal of Public Relations Research, Vol. 16 No. 3, pp. 213-41.

Martin de Castro, G., Navas Lopez, J.E. and Lopez Suez, P. (2006), "Business and social reputation: exploring the concept and main dimensions of corporate reputation", Journal of Business Ethics, Vol. 63, pp. 361-70.

McDonald, L. (2006), "Perceiving is believing: how consumers' attributions about the cause of Ansett Airlines' safety crisis impacted outcomes", Asia Pacific Public Relations Journal, Vol. 6 No. 2, available at: www.deakin.edu.au/arts/apprj/currenti.php\#7

Milgrom, P. and Roberts, J. (1986), "Relying on information of interested parties", Rand Journal of Economics, Vol. 17, pp. 18-32.

New South Wales Government (2004), Report of the Special Commission of Inquiry into The Medical Research and Compensation Foundation, Vol. 1, Part C, pp. 354-8, available at: www.cabinet.nsw.gov.au/hardie/PartC.pdf

Schwaiger, M. (2004), "Components and parameters of corporate reputation - an empirical study”, Schmalenbach Business Review, Vol. 56 No. 1, pp. 46-71.

Sharman, J.C. (2007), "Rationalist and constructivist perspectives on reputation", Political Studies, Vol. 55, pp. 20-37.
Reputation and ethical behaviour in a crisis

383 
$\mathrm{JCOM}$

11,4

\section{4}

SMH.com (2007), "James Hardie profit up, asbestos liability estimate down", available at: www. smh.com.au/news/business/james-hardie-profit-up-asbestos-liability-estimate-down/2007/ 05/28/1180205161229.html (accessed on 29 May, 2007).

Stigler, G.J. (1962), "Information in the labour market", Journal of Political Economy, Vol. 70, pp. 49-73.

Sydney Morning Herald (2001), "Lessons from Ansett", Sydney Morning Herald, Vol. 14, p. 32.

Sydney Morning Herald (2004a), "Way clear for an asbestos resolution”, Sydney Morning Herald, 17 August, p. 10.

Sydney Morning Herald (2004b), "They should go, and go now", Sydney Morning Herald, 1 October.

Wartick, S. (2002), "Measuring corporate reputation: definition and data", Business and Society, Vol. 41 No. 4, pp. 371-92.

Von Weizsacker, C. (1980), Barriers to Entry, Springer-Verlag, New York, NY.

Yoon, E., Guffey, H.J. and Kijewski, V. (1993), "The effects of information and company reputation on intentions to buy a service”, Journal of Business Research, Vol. 27, pp. 215-28.

\section{Further reading}

Gardberg, N.A. (2006), "Reputatie, reputation, reputation, reputazione, ruf: a cross-cultural qualitative analysis of construct and instrument equivalence", Corporate Reputation Review, Vol. 9 No. 1, pp. 39-61.

\section{Corresponding author}

Tom Watson can be contacted at: twatson@bournemouth.ac.uk 